\title{
Die humanistiese mensbeeld
}

\author{
J P Labuschagne \\ Rustenburg
}

\begin{abstract}
The humanistic understanding of man

The main purpose of this essay is to reflect on the humanistic understanding of man, and on the influence it has on the church. For the humanist man's understanding of himself actually determines his own being. On the other hand, what man experiences of his own being and the world he has created for himself occupies his mind, and this again determines his thoughts.
\end{abstract}

\section{INLEIDEND}

Met 'humanistiese mensbeeld' wil ons sê dat ons hier te make het met die mens wat geheel vanuit homself tot verstaan van homself wil kom. Hierdie mensbeeld staan daarom los en onafhanklik van die Bybel se openbaring van God en die mens.

Die beeld wat die mens van sy syn het, laat sy eie syn beslis nie onaangeroerd nie. Die beeld of die verstaan wat die mens van die werklikheid en homself uitmaak, van wat hy is, van sy wese en sy bestemming, bly beslis nie sonder vormende invloed op dit wat die mens in feite is en word nie - in 'n bepaalde stadium van die geskiedenis. Wat die mens van homself dink, bepaal sy kulturele aktiwiteite, en hierdie wêreld wat die mens vervolgens vir homself geskep het, werk weer vormend terug op sy verstaan van homself. Daar is dus 'n voortdurende wisselwerking. Die Middeleeuse mens verstaan homself byvoorbeeld volledig afhanklik van die sentrale gesag van die kerk as verteenwoordiger van God en die hiernamaals op aarde. Met hierdie verstaan van homself en sy wêreld is die Middeleeuse mens, varende op die koers van die kompas van die kerk, grootliks wêreldvermydend en nie ingestel op ontwikkeling en die materiële vooruitgang van hierdie wêreld nie, maar is hy ingestel op 'n bestaan, samelewing en lewensverwagting wat gerig is op die hiernamaals. Daarteenoor het die twintigste-eeuse mens in sy synsverstaan grootliks net homself en hierdie wêreld. Die moderne mens is, so gesien, 'n outonome mens en 'n gesekulariseerde mens. Hierdie synsverstaan bring 'n grootskaalse ontwikkeling op kulturele gebied - wetenskaplik, tegnologies, organisatories (laasgenoemde ten opsigte van 
sosiale, politieke en ekonomiese strukture). Die mens het net homself en hierdie wêreld, en hy is daarop ingestel om vir homself die beste moontlike leefwêreld nou en hier te skep. Al hierdie aktiwiteite werk ook weer terug en skeppend op die beeld wat die mens van homself het. Daarmee is inderdaad reeds gese dat die twintigste-eeuse mens se verstaan van homself tot 'n baie groot mate 'n humanistiese mensbeeld behels, en moet daar nou verwag word dat die humanistiese mensbeeld ook invloed sal hê op die lewensverstaan van lidmate van die kerk sowel as handelswyses binne kerklike strukture. Die vraag is nou na die kwaliteit van die invloed van die humanistiese mensbeeld op die kerklike terrein - of dit goed of sleg is? Maar voordat hierdie vraag beantwoord kan word, moet die humanistiese mensbeeld eers ondersoek en verstaan word.

\section{DIE RENAISSANCE - ONTDEKKING VAN 'N ONGEBONDE EN OUTO- NOME MENS BUITE DIE GESAGSFEER VAN DIE KERK}

$J$ van der Hoeven wys met groot mate van reg daarop dat die hedendaagse mens- en wêreldbeskouing geleidelik voorberei is deur die periode vanaf die Renaissance tot die negentiende eeu. In hierdie voorbereidende periode, sê hy, het 'n 'proefhuwelik' plaasgevind tussen 'Christendom...en humanisme'. As voorbeeld van hierdie verbintenis noem hy die Westerse onderwys wat in hierdie periode moes opvoed tot 'Christelike en maatskaplike deugde' (Van der Hoeven 1974:119, 120).

Die mensbeeld van die vyftiende-en sestiende-eeuse Renaissance is, in die woorde van $I H$ van Riessen, die van 'die mens as 'n soewereine, in vryheid skeppende en roemsugtige individu. Met hierdie idee is die ootmoed van die lewe uit die genade van Jesus Christus nie te rym nie' (Van der Hoeven 1974:25). Die humanisme van die Renaissance-tyd is dan juis daardie beweging wat die aandag primêr op die mens wil vestig, die mens soos geopenbaar in sy geskiedenis, literatuur en kuns. In die antieke Griekse en Romeinse wêreld ontdek die Renaissance-mens 'n ander mens, 'n ongebonde en outonome mens búite die gesagsfeer van die Middeleeuse kerk. Tog bly dit opvallend dat die Renaissance-mens - met sy verering van die mens wat dink en optree sonder die bande wat die kerk hom oplè - nogtans steeds die behoefte behou aan 'n begronding in 'n bowe-sinnelike wêreld, aan 'n metafisies-religieuse fundering van die werklikheid. Die sisteemtyd (rasionalisme) van die sewentiende eeu en die verligtingstyd ( $A$ ufklänung) van die agtiende eeu volg nog op hierdie weg.

Die beroemde homo-mensura-sin van Protagoras (gebore ca 481 v C) dien as inspirasie vir die Renaissance. Johannes Hirschberger wys daarop dat hierdie stelling gedeeltelik reeds deur Cusanus (1401-1464), wat staan op die grenslyn tussen Middeleeue en Renaissance, onderskrywe is. Tog was die mens, vir Cusanus, alleen die maatstaf van alle dinge, omdat die mens die beeld gedra het van die Goddelike 
Oorspronklike. Cusanus was bewus van die aspirasies van die menselike rede, maar hy het dit altyd met iets groter geassosieer: Anderkant die 'ek dink' het hy die Ewige Een, God, gesien (Hirschberger 1976:96). Afgesien van sy waardering van die Bybel, het die verering van die vrye op homself vertrouende Renaissance-mens ook Erasmus van Rotterdam (1466-1536) aangegryp. In sy Aangaande die Vrye Beslissing (De Libero Arbitrio) van 1524 wil hy teenoor Luther groter ruimte vind vir die insigte van die menslike rede en die mens se vrye beslissing in die proses van saligwording. Michel de Montaigne (1533-1592) gaan verder: Die enigste sekere kennis van die mens is, volgens hom, selfkennis. Elke mens kan alleen geoordeel word ooreenkomstig sy eie norm. Montaigne sê: 'Alleen jy self kan jou dade oordeel. Ander sien nie soveel van jou natuur as jyself nie' (Höffding 1955:31). Petrarca (13041374), wat beskou word as die grondlegger van die humanisme van hierdie tyd, hou enersyds vas aan die sedelike outonomie van die mens, maar sluit andersyds dikwels weer aan by die tradisionele Christelike denke. Die vryskeppende krag van die outonome Renaissance-mens spreek baie skerp uit die denke van Giordano Bruno (1548-1600). Wanneer Bruno vervolgens van die mens sê - 'ons is reeds in die hemel' - wil hy daarmee sê dat ons die hemel van die kerk nie meer nodig het nie. Bruno staan vir die soewereiniteit van die Renaissance-individu, die mens wat homself beskou as 'tweede god' (alter deus). Wanneer Bruno uiteindelik deur die kerk vervolg word, is dit nie omdat hy - vanuit die tipiese panteïstiese grondgevoel van die Renaissance - die mens deel maak van die universele ruimtes nie, maar omdat hy die mens verdeifiseer het (Landmann 1971:78, 79).

Tog kom die verdienste van 'n suort 'antropologiese ommekeer' (soos Landmann dit noem) - as die eerste daadwerklike toespitsing op die mens - die sofiste van die vyfde eeu v $\mathrm{C}$ toe. Dit was die sofis, Protagoras, wat gesê het: 'Die mens is

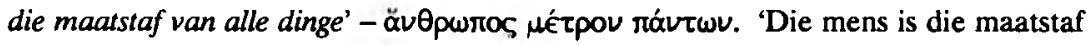
van alle dinge wat bestaan en van die nie-bestaan van die dinge wat nie bestaan nie' (Landmann 1971:37, 41). Spesifiek sofisties is die gedagte wat in ons tyd weer baie prominent is, naamlik dat die mens sy sedewette self voortbring. En hieruit volg dat die individu by magte is om vir homself te beslis wat hy as goed en as geldend beskou. Hierdie beskouing van die sofisme lok vroeg reeds die verset van die Platonisme uit. Plato (427-347 v C) gryp na ewige op sigself staande en tevore vasgestelde norme, wat die mens in sy denke moet ontdek en waarvolgens sy sedelike handelinge konsekwent gerig moet word. Daarmee wil die Platonisme die willekeur uit ons handelinge weer. Wanneer die Platonisme nou vervolgens vir baie eeue die oorwegende koers bepaal, verdwyn die deur die sofiste ontdekte kreatiewe element in die individuele mens, om eers weer in ons tyd sy daadwerklike verskyning te maak. 
Die effektiewe deurwerking van die humanistiese mensbeeld van die Renaissance is egter aanvanklik aan bande gelê deur die magtige invloed wat van die sestiende-eeuse Reformasie uitgegaan het. Die Reformasie het die mens nederig voor sy Skepper gehou - 'n sondaarmens op soek na 'n genadige God, en hierdie ware en enigste God bereik hom as mens alleen in Jesus Christus. Dit was die insig wat van Martin Luther (1483-1546) en Johannes Cahyn (1509-1564) uitgegaan het.

Die hedendaagse uitwerking van die bovermelde humanistiese siening van die mens binne die geledere van die kerk, kom tot uitdrukking daarin dat persone wat wel belydenis van geloof in die kerk afgelê het, vervolgens, sonder om enigsins 'n kwessie daarvan te maak, vir hulleself die reg toe-eien van 'n ongebonde outonome gesag buite die Christelik-etiese gesagswydte van die kerk, byvoorbeeld op die terrein van die politiek en die ekonomie. Die politikus eis dan op die politieke terrein vir homself teenoor sy Christenskap, die reg op van pragmatiese gewetensvrye beslissing, en eis 'n neutraliteit op teenoor die kerk en die voorskrifte van die Christelike etiek op die gebied van die samelewing. Die ekonoom eis weer, teenoor sy Christenskap, die vryheid van die markmeganisme wat vry van staatsinmenging en die kerklike gewete, deur aanbod en aanvraag, vir die kapitaalkragtige die hoogste moontlike wins kan vermag, ongeag die skrikwekkende uitwerking wat dit moontlik op die breë massa van die bevolking kan hê ten opsigte van armoede en werkloosheid. In die samelewing van die Middeleeue en die Reformasie het hierdie gesagsaansprake eenvoudig nie bestaan nie; die kerklike voorskrifte het die hele samelewing aangespreek.

\section{RASIONALISME (17de EEU) EN VERIIGTING (18de EEU) - DIE MENS AS BURGER VAN EEN WERELD}

Die gees van die tyd het gevra na 'n sintese tussen die menslike rede en die Openbaring van God in die Bybel. In hierdie proses is die Openbaring byna konsekwent afgemaak ten gunste van die voorstelling van die rede.

Vir eeue reeds het die kerk egter sy eskatologie gekompromitteer met die tradisionele Platoniese twee-wêreldebeeld. Hiervolgens was die mens burger van twee wêrelde.

Die Platoniese twee-wêreldebeeld bereik egter in hierdie tyd sy hoogtepunt en ineenstorting. Wanneer die invloed van die Engelse empirisme, die opkoms van Newton (1643-1727) se fisika en Immanuel Kant (1724-1804) se kritiek op die suiwere rede die wêreld daartoe bring om voortaan elke kennisvertrekpunt, anders as in die ervaringswerklikheid, te verwerp, is die boodskap van die kerk oor God en die hemel vir baie mense nou ook onder verdenking. Die kerk het eenvoudig vir te lank toegelaat dat die humanistiese mens- en wêreldbeeld hom voorskrywe. Die feit 
dat die kerk die reformasie se onkompromitteerbare gesagsbasis van die sola Scriptura verwaarloos het, het hom duur te staan gekom. Die teologie het duidelik nie antwoorde gehad nie.

In die verwarring het die humanisme die wêreld na 'n nuwe mensbeeld gelei: die beeld van die mens as burger van éen wêreld, slegs die wêreld van nou en hier.

Hoe het dit alles gebeur? Die Platoniese dualisme begin wanneer Plato meerdere betekenis aan die syn toeken: Hy onderskei tussen die syn van die idees en die geworde syn van die sintuiglik-waarneembare wêreld. Reeds in sy Phaidon praat

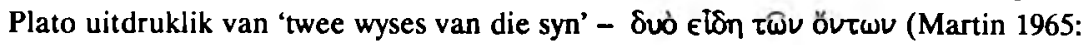
205). Aristoteles (384-322 v C) onderskei die syn van die konkrete individuele dinge wat ons waarneem, en die syn van die algemene idees (as afgeleide syn). Dis egter eers Plotinus (204-270 n C), en die neo-Platonisme wat na hom volg, wat uitdruklik van die bestaan van twee selfstandige wêrelde praat: die sensibele wêreld en die intelligibele wêreld. By Plotinus kry die twee-wêreldeleer 'n mistieke, esoteriese en religieuse karakter. Augustinus (354-430 n C) sluit by Plotinus aan en werk byvoorbeeld in sy $D e$ Trinitate met die neo-Platoniese twee-wêrelde van binne- en buitewêreld, hoër en laer, geestelik en vleeslik. Tog bly Augustinus meer getrou aan die Bybel en die teologie. Thomas van Aquinas (1225-1274 n C) bring 'n swaai van Plato na Aristoteles, en interpreteer Aristoteles byvoorbeeld so in sy teologisering dat die onsterflikheid van die siel 'n dogma sou wees wat gefundeer is in die kapasiteit van die siel om die universele en ewige in te sien en te wil. Daarmee word die basis gelê vir die teologie se voortgaande akkommodering van die humanistiese twee-wêreldebeeld, ook in die tyd van Jie rasionalisme en verligting. In hierdie tyd maak Descartes (1596-1650) 'n fundame ttele synsonderskeid tussen res cogitans en res extensa, Leibniz (1646-1716) tussen die ens reale van die monades en die ens mentale van die fenomene, en Kant tusse a Erscheinung en Ding an sich. En na Kant betwyfel die wêreld toenemend die bestaan van 'n 'ander wêreld' (Hinterwelt) en word die mens toenemend in die humanistiese mensbeeld slegs burger van één wêreld, hierdie wêreld. Die ander wêreld word as metafisies afgemaak. Binne die kringe van die negentiende-eeuse positiwisme, materialisme en biologisme ontwikkel nou selfs 'n anti-metafisiese mens- en wêreldsiening. Die positiwisme lei die ateïsme in - omdat God en 'n wêreld anderkant hierdie wêreld nie vir hulle bestaan nie; die natuurwetenskaplike kenvermoë van die mens is immers nie in staat om empiriesverifieerbare feite oor God en die hemel te versamel nie. Auguste Comte (17981857), vader van die positiwisme, sê in sy Positiewe Filosofie (Cours de Philosophie Positive) dat ons kennisverwerwing 'agtereenvolgens beweeg deur drie verskillende teoretiese kondisies: Die teologiese, of fiktiewe, die metafisiese of abstrakte, en die wetenskaplike of positiewe....' Die eerste twee kondisies is vir hom 'n 'tevergeefse 
soeke' (Aiken 1956:124, 125). Een van die groot figure van die neo-positiwisme, Ludwig Wittgenstein (1889-1951), sê kort en bondig: Vrae waarop geen sinvolle antwoorde moontlik is, is reeds as vrae sinloos (Van der Hoeven 1974:131). Positiwiste, soos Rudolf Camap (1891-1970) en Alfred Jules Ayer (gebore 1910) meen dat hulle vandag reeds daarin geslaag het om alle teologie en metafisika finaal te elimineer. Ayer (in Antonites 1974:76) sê: 'En indien "God" 'n metafisiese term is, dan kan dit nie eens waarskynlik wees dat daar 'n god bestaan nie. Want om te sê dat "God bestaan", is om 'n metafisiese uitlating te maak...Alle uitsprake aangaande die natuur van God makk geen sin nie....'

Dit is nou eenmaal so dat daar dinge is wat ons kan waarneem en ervaar, maar nie kan verstaan of verklaar nie, en daarom moet ons ruimte laat vir die moontlike, die nog-nie, en die onkenbare. Die onhoudbare oorvereenvoudiging van die positiwisme lê nou juis daarin dat dit nie hiervoor ruimte laat nie.

Tog het al die genoemde gebeure daartoe bygedra dat die moderne humanistiese mensbeeld die mens oorwegend, of selfs uitsluitlik, sien as slegs 'n burger van hierdie wêreld sonder enige verbinding met God en 'n ander wêreld. Wat die kerk en teologie dan nou ook sê ten opsigte van die mens en sy wêreld, het vir baie daarom weinig of geen betekenis nie. Hierdie mens verlaat hom toenemend op die vakwetenskap, en die tegnologie, terapie en voorskrifte wat daaruit volg, vir die goeie voortgang van sy bestaan. Hierdie mens voel hom alleen seker van hierdie wêreld en wat mense van hierdie wêreld maak - dit is die gesekulariseerde mens.

Die hedendaagse uitwerking van die humanistiese gerigtheid op hierdie wêreld skep binne die geledere van die kerk Christengelowiges wat byvoorbeeld baie onseker is oor die hiernamaals, wat hoofsaaklik gerig is op wat Christenskap vir hulle beteken in hierdie wêreld met al sy aktiwiteite en aspirasies. Die dood word dan moeilik verwerk, en dood en die hiernamaals word dan geheel negatief ervaar as iets wat geheel teen die gang en die doel van hierdie wêreld inwerk. Die belofte van die hiernamaals is tot ' $n$ mate selfs ongevraagd, die sin daarvan word nie ingesien nie. Ook dit is totaal anders as die siening van die mens van die Middeleeue en die Reformasie.

\section{ANTROPOSENTRISME VAN DIE NEGENTIENDE EEU - DIE SEKURI- TEITE VAN DIE SELFGENOEGSAME MENS}

Teen die negentiende eeu is die beeld van die outonome en ongebonde mens voltooi - dan is daar weinig oor van die Renaissance-behoefte aan 'n metafisiesreligieuse begronding. Op hierdie stadium maak die nuwe metafisika van die veronderstelde selfgenoegsame mens sy verskyning. In die wêreld van die antroposentrisme word die begronding nie meer in God of die metafisika van 'n bowe-sinnelike 
wêreld gesoek nie, maar in iets van die mens en sy onmiddellike wêreld. Geloofsekuriteite maak plek vir sekuriteite in die mens en sy wêreld. Ons onderskei enkele kategorieë van menslike sekuriteite van hierdie periode, die determinante waaruit die mens die werklikheid, en alles wat vir hom belangrik is, wil verklaar. (En dit is alles, ten spyte van anti-metafisiese uitsprake, tog ook weer in talle veronderstellings wat gemaak word, 'n nuwe metafisika.)

\subsection{Biologisme}

Die biologisme wil, in sy verwerping van vergeesteliking en enige metafisiese begronding, die werklikheid verklaar primêr vanuit die lewe self, vanuit een of ander biologiese determinant. So wil die biologisme die menslike gees verklaar as enkel 'n soort lewe. Auguste Comte wil byvoorbeeld die psigologie in die biologie laat opgaan. Volgens $E$ H Haeckel (1834-1919) is die mens enkel die hoogste ontwikkeling van die organiese eiwit.

Vir die pragmatisme het die gees sy kriterium in 'nuttigheid vir die lewe' (Landmann 1971:112). Die Angelsaksiese pragmatiste - $W$ James (1842-1910), J Dewey (1859-1952) en F C Schiller (1864-1937) - leer dat die gees uit die lewe sy bestaan ontvang en van die lewe sy direksies kry. Die gees volbring sy eintlike taak, naamlik kenning, in opdrag van die lewe. Die gees strewe na waarheid in sover dit van lewensbelang is. Of waarheid nou ook al gevind word of nie, is nie soveel van belang nie as net dat dit, wat waarheid veronderstel, prakties-doeltreffend die lewe sal dien.

Nietzsche (1844-1900) dink ook biologisties wanneer hy die siening huldig dat alle voortbrengsels van die gees slegs 'simptome' van die lewe is. Hoeseer ons kennis en oortuigings uit die lewe self voortkom en aan die eise van die lewe ondergeskik is, het Nietzsche veral probeer aantoon op die terrein van ons morele oortuigings. In sy Genealogie der Moral sê hy dat die moraal van die heersers simptoom van hulle magswil is, en dat die waardes van die edele en vername mens in hierdie moraal domineer. In die moraal van die Schlechtweggekommenen (hulle wat lewe vanuit 'n minder bedingende posisie) domineer weer gematigdheid, sagmoedigheid en medelye. Laasgenoemde noem hy 'slawemoraal'. Uiteindelik sê Nietzsche uitdruklik in sy Gotzen-Dämmerung (Skemering van die afgode) ware moraliteit word gedomineer deur 'n instink van die lewe'. Die 'wil tot mag' (Wille zur Macht) is dit waar die lewe ten slotte om draai (Labuschagne 1987:200-204).

Ook Sigmund Freud (1856-1939) dink biologisties wanneer hy stel dat die van nature seksueel gerigte energieë in die mens gedurig soek na uitingsvorme, en so, byvoorbeeld, omsit in filosofiese, artistieke, etiese en religieuse energieë. So is die gees uiteindelik vir Freud 'n epifenomeen ('n masker) van die daaragter skuilende 
libido, 'n ontwikkelingsproduk van die libido wat hom tot gees gedistilleer het. Die libido (die seksuele drif en begeerte) is vir Freud die primum movens (die eerste beweegkrag) in die mens (Labuschagne 1987:204, 205).

\subsection{Darwinisme}

Gedurende die laaste dekades van die negentiende eeu het die Darwinisme vir baie die leemte van onsekerheid gevul in hierdie tyd van 'los-van-God'-beweging en Kulturkampf, nadat die ou mens- en wêreldbeskouing sy sekuriteite verloor het en die kerk ook nie die regte antwoorde gehad het nie. Die ontwikkelingsbegrip het in hierdie tyd 'n towerwoord geword waarmee mense alle poorte wou oopsluit. Die ontwikkelingsidee het ' $n$ welkome middel geword om alles tot materie terug te voer - die naturalisme vier hoogty.

Wanneer Charles Darwin (1809-1882) die mens dan binne die kader van die natuur plaas, is die mens vir hom daarmee louter natuur. Die gees is alleen die laaste ontwikkelingsproduk van die steeds fyner organiserende materie. Hoewel Darwin ook soms beweeg in die rigting van 'n spontane generasie as die oorsprong van alles, is die tipiese gedagte van die Darwinisme dat alle bestaan en ontwikkeling verband hou met natuurlike seleksie. Stryd is hiervolgens die universele wet van die natuur. Die 'stryd om bestaan' behels 'n aanpassing van die lewende organisme by sy lewende of lewelose omgewing. Van die kant van die omgewing volg 'n 'natuurlike seleksie' waarvolgens sekere kwaliteite in die lewende organisme bevorder word en ander nie. In hierdie wisselwerking word die voortbestaan van die bepaalde lewende organisme sowel as sy afstammelinge bepaal. In sy The origin of species (1859) het Darwin geen twyfel nie dat die wette, waarvolgens nuwe soorte in die natuur ontstaan, ook op die ontstaan van die mens van toepassing is. Eers in Darwin se The descent of man (1871) vind ons wat populêr daarop neerkom dat die mens afstam van 'n dier, en dan spesifiek van die aap. En dit word dan later beskou as die eintlike Darwinisme (Labuschagne 1987:205-210).

Hoewel die ontwikkelingsgedagte vandag nog steeds aanvaar word, bestudeer wetenskaplikes mens en dier as 'n wese wat elkeen op sy eie reg bestaan. Denkers en navorsers sien die gemeenskaplike nie meer as die dierlike nie, maar eerder as 'n mens-en-dier-neutraal-omspannende-organiese waaraan beide mens en dier in menige opsig deel het (Landmann 1971:151, 152).

\subsection{Materialisme}

Die negentiende-eeuse verering van die natuurwetenskaplike metode het die trefwydte van die verwerwing van kennis via die kategorie van meganiese kousaliteit (scire est per causa scire - kennis is aan die hand van oorsake kennis) totaal oorskat. 
Tog is daar vandag nog in humanistiese geledere sprake van 'n bykans perkelose verering in hierdie verband. Die negentiende-eeuse materialisme is 'n fisikalistiese en meganistiese materialisme. Dit wil alles nie slegs terugvoer tot materie nie, maar wil bowendien alles verklaar vanuit kwantitatief-meganiese prinsipes.

Die moderne materialisme kan basies teruggevoer word tot op die antieke Griekse atomisme van Democritus (460-360 v C) en Epicurus (341-270 v C). Hiervolgens word alles gevorm deur 'n samestelling van verskillende atome. Selfs denke word in fisiese terme verklaar. Die Renaissance bring die antieke Griekse denke weer onder die aandag. Onder die materialisme van die verligtingstyd is dit veral Julien Offray de la Mettrie (1709-1750) wat opval. In sy boek L'homme machine (Die mensmasjien) van 1748 beskou hy die menslike siel as niks anders nie as denkende en voelende materie.

Die moderne geesgenote van La Mettrie was Baron Holbach, en verder Mandeville in Engeland, en Moleschott en Ludwig Büchner in Duitsland. Dit was Ludwig Büchner (1824-1899) wat gesê het: 'Die harsings skei gedagtes af soos die niere urine afskei' (Landmann 1971:119). Ludwig Andreas Feuerbach (1804-1872) en Karl Marx (1818-1883) se denke kan in bepaalde sin ook onder die materialisme begryp word; hulle ken immers geen wêreld buite die sigbare materiële werklikheid nie.

\subsection{Een ondeelbare mensheid}

Die ontwikkeling van die nuwe mensbeeld word sedert die agtiende eeu gekenmerk, enersyds deur, wat Michael Landmann noem, 'n 'dwepery met die "natuurvolke"', en andersyds deur die gedagte van één ondeelbare mensheid. Vir Friedrich Schiller (1759-1805) het dit tot gevolg gehad dat 'alle mense broers' is. Vir die rasionalisme en die verligting is dit egter eers die rede wat alle mense mense, één mensheid maak.

Die rasionele antropologie handhaaf nog die antropologiese dualisme van die gees in 'n hoër rangorde teenoor die liggaam. Alle aandag word dan gevestig op die rasionele mens. En die mensheid word gesien as gelykwaardig in almal se gehoorsaamheid aan die wette van die rede. Die liberalisme, wat in die negentiende eeu sterk opkom, handhaaf ook met groot klem die beskouing van een ondeelbare mensheid, maar wil dan veral daarop wys dat die eenheid uit individue bestaan. Voorts is die aandag veral op die vrye individu gerig.

Dit was die sofiste wat vir die eerste maal die gelykwaardigheid van alle volke verkondig het, waar die Griekse tradisie sedert Homeros (ca $8 \mathrm{e}$ eeu v C) na die vreemde volke minagtend as 'barbare' verwys het, en Aristoteles slawerny probeer regverdig het. So sê die sofis, Hippias (ca 500 v C): 'Want van nature is ons almal in 
elke opsig gelyk, hetsy barbare, hetsy Helleniste' (Landmann 1971:26). In die Romeinse wêreld gee Cicero (106-43 v C) aan die woord humanitus'n ryker betekenis om daarmee aan te toon dat die skeiding tussen Romeine en nie-Romeine (of barbare) vervaag voor die humane mens wat die grense van alle volke oorskry.

\subsection{Verskeidenheid in die mensdom}

Teenoor rasionalisme, verligting en liberalisme ontwikkel die besef in die Duitse romantiek dat die één mensheid hom tog ook baie duidelik in groepe en verskillende volke onderskei. Veral $J G$ Herder (1744-1803) kom in hierdie opsig sterk na vore. Vir die Duitse romantiek bestaan daar eenvoudig nie iets soos 'n algemene mens nie: Elke mens is uniek as individu en as volk. Die Duitse romantiek ontdek eenheid in 'n unieke verskeidenheid.

Soos in Cusanus en Leibniz se mensbeeld en wêreldbeeld die wêreld uit selfstandige individue bestaan, sodanig dat geen enkele individu (of deeltjie of watter monade ook al) presies dieselfde is as 'n ander nie, maar elkeen op sy eie wyse die hele wêreld weerspieël (in alle dele weerspieël die geheel hom - in omnibus partibus relucet totum), so gee elke volk volgens J G Herder op sy eie manier uitdrukking aan die een mensheid. Herder eis verdraagsaamheid, omdat verskille geduld moet word en respekteer moet word en juis omdat in die verskille die kosbaarste in die mens geleë is (Landmann 1971:33). Daar is by Herder geen sprake van etnosentrisme en rasse- of volkeremeerderwaardigheid van een teenoor 'n ander nie.

\subsection{Homo oeconomicus - die geldmens}

Die negentiende eeu openbaar duideliker as ooit tevore dat die humanistiese mensbeeld ook uitdrukking gee aan die geldmens wie se samelewing op 'n ekonomiese basis gebou word. In hierdie verband ontwikkel in die praktiese stryd van die samelewing en sy mense veral drie duidelike ideologiese strominge waarin die geldmens na vore tree. Liberalisme-kapitalisme vanuit die denke van Adam Smith (17231790), demokratiese-sosialisme vanuit die denke van Jean Jacques Rousseau (17121778), en Marxisme-kommunisme vanuit die denke van Karl Marx (1818-1883).

In elkeen van hierdie ideologiese strominge bestaan 'n mensbeeld soos dit bepaal word deur ' $n$ sekere verdeling van rykdom deur die spesifieke ekonomiese strukture wat daargestel word. Die strukture skep so rykes en armes.

$G W F$ Hegel (1770-1831) het reeds in sy kritiek op die negentiende-eeuse liberalisties-kapitalistiese samelewing, wat hy die 'burgerlike samelewing' (büngerliche Gesellschaft) noem, daarop gewys hoe die samelewing deur die ekonomiese kragte van die mark uiteindelik enersyds 'rykdom in min hande...konsentreer' en 'ophoping van rykdom' daarstel, en andersyds die 'daling van 'n groot massa onder 
die vlak van 'n bepaalde bestaanswyse' en 'n 'oormaat van armoede en die ontstaan van die gepeupel' (Hegel 1955:200, 201).

Karl Marx het in sy Kommunistiese Manifes (1848) daarop gewys dat die ekonomiese basis van die samelewing ' $n$ bepaalde mens skep met bepaalde idees en konsepsies. Marx bou voort op die gedagtes van Hegel.

Adam Smith, vader van die kapitalisme, beywer hom vir die vrye onderneming van mededingende individue wat hulle produkte op die mark plaas wat, vry van inmenging van buite, suiwer deur aanbod en aanvraag prys vir produkte en dienste bepaal. Rykdom word so uitgedeel en verdeel deur die 'onsigbare hand' van die mark.

Vir Jean Jacques Rousseau kan welvaart slegs regverdig verdeel word wanneer gesoek word na 'n balans tussen die vryheid en regte van die individu aan die een kant, en die vryheid en regte van die gemeenskap aan die anderkant. Vir Rousseau moet die etiek die koers aandui, en die instrument om die doel te bereik, is die demokrasie. Die ekonomie moet ter wille van geregtigheid dan inderdaad ook deur die demokratiese owerheid reguleer word. Alleen so word uiteindelik 'n werklik vrye mens geskep.

Die hedendaagse uitwerking van wat die humanistiese mens voorhou as sekuriteite van die lewe, het binne die geledere van die kerk byvoorbeeld tot gevolg dat gevind word dat Christengelowiges geloofsekuriteite op die agtergrond plaas en eerder sy lewe sinvol wil uitmaak op basis van wêreldse sekuriteite. Miskien is dit dan primêr byvoorbeeld 'n pragmatiese verklaring van sy menswees, as gerig deur 'n strewe wat prakties-doeltreffend in diens staan van die voordeligste lewe moontlik. Miskien maak die lewe vir hom, afgesien van sy Christenskap, alleen sin op grond van die sieninge van die geldmens; geld is dan die primêre sekuriteit. Weer eens was die primêre sekuriteite van die Middeleeuse mens en die mens van die Reformasietyd vanuit die kerk ontvang.

\section{DIE FUNKSIONELE KULTUUR VAN DIE TWINTIGSTE EEU - 'N GESLOTE WêRELD}

Teen die twintigste eeu het die humanistiese mensbeeld ontwikkel tot die daarstelling van 'n mens wat:

- homself 'n eie gesag toe-eien teenoor die gesagsfeer van die kerk;

* in sy beskouings en aktiwiteite gerig is op die wêreld van hier en nou;

* 'n vrye outonome en selfgenoegsame mens is wat sy sekuriteite in die lewe nie van geloof, kerk en godsdiens ontvang nie, maar in en op die wêreld gerigte oortuigings, ondersoekresultate, ideologieë, samelewingstrukture, organisasies, aktiwiteite en geld. 
Omdat die kerk hom in hierdie wêreld bevind, moet verwag word dat die humanistiese mensbeeld invloed sal hê in die kerk.

Wanneer ons die nuwe en tipiese van die twintigste-eeuse humanistiese mensbeeld wil raakvat, doen ons dit waarskynlik die beste deur te gryp na 'n begrip van $C A$ van Peursen. Dan sè ons dat die twintigste-eeuse mensbeeld veral bepaal word deur die funksionele kultuufase waarin die mens homself tans bevind (Van Peursen 1975:80-111). In hierdie kultuur vind ons 'n mens wat nie sonder meer alles aanvaar wat 'substansialisties' (as verabsoluteerde groothede) op hom afgedwing word nie dit is al die, asof kritiekvrye, verabsoluteerde groothede van beskouings, modes, tradisies, stelsels, strukture, godsdienstighede, waardes en norme, wette, owerheidsmagte, besigheidsmagte en die beslissings van die mark, die natuur ensovoorts - alles dinge waaronder die mens in die geskiedenis met soveel passiwiteit en gelatenheid soveel gely en verduur het. Die mens van die funksionele kultuur aanvaar of verwerp alles vanuit die besinning en ervaring van 'hoe', hoedanig, in watter 'relasie' die dinge tot hom staan, en of dit 'n 'funksie' het wat 'sin' (betekenis en kwaliteit) 'prakties' aan sy lewe en sy wêreld van nou en hier verleen. (Daarmee is sterk aangesluit by Van Peursen.) Waar daar 'n godsdienstige aanvoeling wel bestaan, moet ook die distansie tussen God en mens opgehef word en moet God aarde toe kom en histories betrokke wees. 'n Mondige bevolking het sy verskyning gemaak, wat 'optimale partisipasie' eis op alle lewensterreine - in die opvoeding en onderwys, godsdiens, ekonomie, en in die sosio-politieke ordening. John Naisbitt (1984:159v) praat van deelnemende demokrasie ('participatory democracy') as een van die groot onkeerbare strome van ons tyd. Die leidende beginsel van deelnemende demokrasie is dat mense op direkte wyse deel moet wees van die besluitnemingsproses wat hulle lewe op elke terrein raak. En volgens Naisbitt sal veral die politiek en die ekonomie ingrypend hierdeur geraak word in die toekoms. Laissez faire is ten ene male uit vir die toekoms van die mondige mens. Verantwoordelikheid en etiek kom al meer in die gesigsveld en strategie. Van Riessen, en ook ander, onderskei drie groot mensemagte waarop die mens van die funksionele kultuur vertrou: wetenskap, tegniek en organisasie (Van der Hoeven 1974:21v). Die mens van die funksionele kultuur is gerig op die praktyk en afkeurig van geslote sisteme en gearriveerde denke. Die waarheid en toekoms is oop. Alles is in beweging na 'n nuwe en beter wêreld - vir die mens. Tog is die mees kenmerkende van dié moderne kultuur waarskynlik dat die mens homself nou in 'n geslote wêreld bevind waarin die mens alleen is, volledig op homself aangewese. Immanensie (geslotenheid) spreek uiteindelik van onsekerheid en angs in 'n wêreld sonder God - waarin die mens net homself het.

In hierdie geslote wêreld van die twintigste eeu het van etiese kant Max Scheler (1874-1928) en Nicolai Hartmann (1882-1950) geheel tot 'n postulatoriese ateïsme 
gekom, om Scheler se eie woorde te gebruik (Landmann 1971:77). Hartmann en Scheler redeneer dat die sedelike mens eers tot sy reg kan kom wanneer God noodsaaklik uitgeskakel is. Hartmann sê: Godsdiens vernietig die mens as morele persoonlikheid (Landmann 1971:77).

Neo-Marxiste, soos Habermas, Adorno en Marcuse, protesteer teen wat hulle sien as die slawerny onder die verselfstandigde magte van wetenskap, tegniek en organisasie, magte wat ideologies geprogrammeer is deur diegene wat daarby baat. Kortom, vir hedendaagse neo-Marxiste, soos veral Marcuse en Habermas, lê die dialektiese spanning tussen die verselfstandigde magte van die samelewing en die vryheid van die mens wat daardeur bedreig word. Die beeld van die vervreemde mens word hier gestel.

Immanensie in die twintigste-eeuse wèreld lei die eksistensie-filosofie daartoe om die mens te sien as in 'naakte vryheid' op homself 'teruggewerp', en 'op homself aangewese' (Labuschagne 1987:217). Martin Heidegger (1889-1976) sê: 'Soos 'n geworpene is hy in die eksistensie gewerp. Hy eksisteer as synde wat, soos hy is en soos hy kan wees, moet wees.' (Als geworfenes ist es in die Existenz geworfen. Es existiert als Seiendes, das, wie es ist und sein kann, zu sein hat. - Heidegger 1935:276). Dit beteken dat die mens in 'naakte vryheid' aan niks en niemand buite hom kan vasklou nie. Sonder hulp van buite, van een wat sterker is, is die mens as onvoltooide wese besig om homself te word. $H L$ Bergson (1859-1941) sè: 'Menswees beteken mens word' (Landmann 1971:50). Die menslike ontplooiing is 'n kontoerlose, na die toekoms oopstaande voortgang, sê Bergson en Karl Jaspers (1883-1969) (Landmann 1971:188). So is die mens dan uiteindelik sy eie ontwerp, sy eie eksperiment, en hy is geroep om die risiko van die vryheid en die verantwoordelikheid daarvoor volledig op hom te neem. Vir Jean-Paul Sartre (1905-1980) is die mens eenvoudig wat hy van homself maak. En hierin is hy 'tot vryheid gedoem'; hy verkeer immers in die noodsaak om vry te moet wees. Wat die mens in vryheid van sy lewe maak - sukses of mislukking - aan dit alles het die mens self vorm gegee, en hy is self volledig daarvoor verantwoordelik. Sartre sê: Die mens is 'gedoem tot verantwoordelikheid' (Sartre 1977:555, 556). Juis dit alles gee aanleiding tot 'n gevoel van 'angs' (angoisse). Vir Sartre is die mens inderdaad 'gedoem tot angs'. Om angs te probeer ontvlug, is om te verval in 'kwade trou' (mauvaise foi). Die mens durf daarom nie swig voor angs nie; hy moet in verantwoordelikheid voor homself en die hele mensdom sy keuses maak en optree. Uiteindelik is menswees 'n geleentheid om te kan kies in elke situasie. Sartre sê: 'Wat ek gekies het, kies ek van dag tot dag myself, en ek maak dit myne deur myself te maak....' So vra die lewe en menswees, in die woorde van Paul Tillich 'die moed om te bestaan' (Labuschagne 1987:234-239, 243). 
Die hedendaagse uitwerking van die humanistiese geslote wêreld op kerkmense skep byvoorbeeld 'n mens wat uiteindelik ontdek dat hy in moeilike omstandighede baie onseker en intens alleen is, as mens wat net homself het om op staat te maak. In sy vrye outonome sedelike beslissing kom hy uiteindelik nie verder as menslike willekeur nie - uiteindelik is hy gedoem tot willekeur. Die afstand tussen hom en God dreig dan om telkens te groot te word. Deur immanensie verloor hy om raak te sien dat die belangrikste vir ons lewe daarin geleë is dat God na ons toe gekom het in die historiese Jesus, ons Verlosser, en dat Jesus Christus as oorwinnaar vir ons waarlik opgestaan het uit die dood, voor die oë van die hele wêreld.

\section{SLOTOPMERKING - OOPBUIGING VAN DIE GESLOTE WERELD}

In die humanistiese mensbeeld vind ons 'n mens wat in 'n gekompliseerde moderne wêreld toenemend vra na koers en rigting van die kant van die etiek. Karl Barth (1886-1968) sê egter, 'die etiese probleem is die krisis van die mens, die mens se siekte tot die dood...' (Karl Barth 1957:151, 152). Want, sê Barth, die mens is 'n gebore sondaar, en hoe sal hy onderskei tussen goed en kwaad. Die ware etiek is vir Barth alleen moontlik wanneer God self in ons wêreld intree in Jesus Christus, en die geslote wêreld weer bevrydend oopbuig, om die 'nuwe mens' in ons te skep, die nuwe mens op grond van vergewing van sondes (Karl Barth 1957:145-182).

Dis noodsaaklik om kennis te neem van die humanistiese mensbeeld en sy invloed in die kerk. Dis egter meer noodsaaklik om nooit te verloor nie wat die Bybel se Openbaring ons leer van die mens: 'n verlore sondaar voor God en die wêreld, maar in Christus, op grond van versoening en vergewing, bestem vir die nuwe mens wat in ware geregtigheid (etiek!) en heiligheid sy koers vind. Dít mag nooit in al die arbeid van die kerk uit die gesigsveld verdwyn nie. Sonder hierdie Bybelse antropologiese insigte kan die kerk nooit sy bevrydende boodskap sinvol uitdra nie. Alle ander antropologiese insigte is beslis daaraan ondergeskik.

\section{Literatuurverwysings}

Aiken, H D (ed) 1956. The age of ideology: The 19th century philosophers. Selected, with introduction and interpretive commentary by H D Aiken. New York: Mentor Books.

Antonites, A J 1974. Die metafisiese wêreld. HTS 30/3 \& 4, 75-92.

Barth, K 1957. The Word of God and the Word of Man. Transl by D Horton. New York: Harper.

Hegel, G W F 1955. Grundlinien der Philosophie des Rechts. Hamburg: Verlag von Felix Meiner. 
Heidegger, M 1935. Sein und Zeit. Halle: Max Niemeyer Verlag.

Hirschberger, J 1976. A short history of western philosophy. Transl by J Moiser. London: Lutterworth Press.

Höffding, H 1955. A History of Modern Philosophy, vol 1. Transl by B E Meyer. New York: Dover Publications.

Labuschagne, J P 1987. Die historiese konteks van 20ste-eeuse samelewingsteologieë. DD-proefskrif, Universiteit van Pretoria.

Landmann, M 1971. Filosofische Antropologie. Vertaal deur A van Dijk. Antwerpen: Het Spectrum.

Martin, G 1965. Allgemeine Metaphysik: Ihre Probleme und ihre Methode. Berlin: De Gruyter.

Naisbitt, J 1984. Megatrends: Ten new directions transforming our lives. London: Futura.

Sartre, J-P 1977. Being and nothingness. Transl by H E Barnes. Bristol, England: J W Arrowsmith.

Van der Hoeven, J, Goudzwaard, B, Van Riessen, H \& Rookmaker, H R 1974. Macht en onmacht van de twintigste eeuw. Amsterdam: Buiten en Schipperheijn.

Van Peursen, C A 1975. Cultuur in stroomversnelling: Strategie van de cultuur. Amsterdam: Elsevier. 